\title{
Prospects of Poverty Eradication Through the Existing Zakat System in Pakistan
}

\author{
FAIZ MOHAMMAD
}

Zakat which literally means growth, extension and purification is a premium (in most cases annual) on all forms of accumulated productive wealth and on a variety of agricultural produce. It is calculated at various rates according to the nature of the asset or product, and is due to 'the needy' (Mustahqueen or Mustahiq for singular) of the Muslim community. ${ }^{1}$ It is one of the five basic tenets of Islam and besides being an obligatory act of worship, it is a system through which a Muslim society can eradicate poverty and inequalities [Qardhani (1981)].

In Pakistan till recent years people used to pay their zakat to the needy on self-assessed basis without involving state functionaries. However, following the Sunni Muslim view that collection and disbursement of one of the functions of an Islamic state, a system to this effect was introduced for the first time in Pakistan in 1980. Accordingly the collection of zakat on non-agricultural assets started in June 1980 (Ramdan 1400) and that of ushr (i.e. zakat on agricultural produce) from $R a b i$ season of 1983.

The introduction of the zakat system in Pakistan is indeed a unique experiment of transforming religious ideals in practical institutions. Given the experience of one decade now, it would, therefore, be useful to see as to what extent the system as practiced in Pakistan has the potential to eradicate poverty from society. The present paper is an attempt in this direction. It is drawn from an overall study of the zakat system in Pakistan based on primary data collected through a random sample survey.

Section one outlines the zakat system as practiced in Pakistan followed by a brief description of the sample survey used for collection of data partly used in this paper in section two. In section three we present estimates of zakat potential of the existing zakat system and then compare the same with the actual needs of poverty eradication presented in section four. Finally, some tentative conclusions of the paper are presented in section five.

Faiz Mohammad is Professor at the International Institute of Islamic Economics, International Islamic University, Islamabad.

${ }^{1}$ For discussion on the concept of Mustahqueen in Islam see Qardhavi (1981). 


\section{ZAKAT SYSTEM IN PAKISTAN ${ }^{2}$}

The existing system of zakat is composed of one Central Zakat Administration at the federal level, one Provincial Zakat Council in each province, a District Zakat Committee in each district, a Tehsil Zakat Committee in each tehsil (or sub-division) and a Local Zakat Committee (LZC) in each locality. All zakat collected officially through banks and other agencies are deposited with the Central zakat Administration which releases specified amounts from time to time to Provincial Zakat Councils. A major share of these funds are then passed on to LZCs through the District Zakat Committees. In this way, the actual disbursement of zakat to the needy is done mainly by LZCs' whereas disbursements to institutions (hospitals, religious schools and welfare organizations etc.) and mustahiq students are done by the Provincial Zakat Council.

At present, zakat is collected officially at the rate of 2.5 percent only on eleven assets contained in the First Schedule of the Zakat and Ushr Ordinance of 1980. Those assets are: (1) Saving Bank Accounts; (2) Notice Deposit Accounts and Receipts; (3) Fixed Deposit Accounts and Receipts; (4) Saving/Deposit Certificates Accounts and Receipts; (5) National Investment Trust (NIT) Units; (6) Investment Corporation of Pakistan Mutual Funds Certificates; (7) Government Securities on which the return is receivable by the holder periodically; (8) Securities including Shares and Debentures of Companies and Statutory Corporations on which return is paid; (9) Annuities; (10) Life Insurance Policies; and (11) Provident Fund Credit Balances. ${ }^{3}$

All other assets are part of the Second Schedule and are not subject to compulsory levy of zakat. Sahib-e-Nisab ${ }^{4}$ are however expected to pay on selfassessed basis. ${ }^{5}$

Valuation of assets for compulsory zakat is done on the first day of Ramadan (the 9th month of Islamic calendar).

Ushr is collected on compulsory basis at the rate of 5 percent of the produce from every land-owner, grantee, allottee, lessee, lease-holder or land-holder (except the one excluded from the definition of Sahib-e-Nisab). An individual farmer is exempted from ushr if he is himself a mustahiq or if his produce is less than $948 \mathrm{~kg}$ of wheat or its equivalent in value. The farmer has been given the op-

${ }^{2}$ For this section we have relied heavily on Ahmad (1983) and Butt (1990).

${ }^{3}$ For exact titles of the assets in Schedule one see Ahmad (1983).

4"People holding assets valuing 612.32 grams of silver, a cash or gold or good for trade or any asset liable to zakat under Shariah, the aggregate value of which is equal to the value of 612.32 grams of silver, or 87.48 grams of gold are called Sahib-e-Nisab". Ahmad (1983).

${ }^{5}$ For details see Ahmad (1983), op. cit. 
portunity to assess his ushr at his own but an LZC may also make its own assessment. An assessee has been allowed to reduce his ushr liability by one-third if land was irrigated by tubewells and by one-fourth if irrigated by other means.

\section{DATA}

Data for this study is drawn from a random sample survey based of LZCs, Zakat Recipients, and the General Population (households not receiving zakat from the official channels), conducted in September and October, 1988. In total, 257 LZCs were selected from the aggregate figure of 36658 , using multistage sampling techniques whereby on the first stage one tehsil from each district was selected randomly and, depending on their population sizes, 2-3 LZCs were selected from each tehsil. In the next stage, 4-7 zakat recipients, and about the same number of households from general population, were selected from each LZC. In this way the sample size in each case was about 1050 .

The respondents were asked a variety of questions relating to their knowledge of their localities, the zakat system, their payments of zakat and their assessment of Mustahqueen in their localities. The zakat recipients, drawn from the list of LZCs, were asked about their incomes and expenditures and zakat received from different sources. There were two categories of zakat recipients: (1) those receiving a subsistence allowance from LZCs; and (2) those receiving funds for permanent rehabilitation.

\section{ESTIMATES OF ZAKAT AND MUSTAHQUEEN-E-ZAKAT}

\section{Zakat and Ushr Potential}

Based on the data collected from our survey and some secondary sources, estimates of the maximum amount of zakat funds which could be collected in 1988 are presented in Table 1. Separate estimates for zakat and ushr are presented as per the following details.

\section{Moximum Voluntary Zakat}

This is equal to the average amount of zakat which an LZC can collect with maximum efforts multiplied by the total number of LZCs in a given region. 
Table 1

Estimates of Zakat and Ushr Potential in Pakistan by Region, 1988 '

(Rs in Billion)

Balo-

Source of Zakat

Pakistan Punjab Sindh NWFP chistan

1. Voluntary Zakat

Potential under

Existing Arrangement

$\begin{array}{llll}3.05 & 2.01 & 0.45 & 0.10\end{array}$

0.019

2. Official Zakat

Collection in 1988

from Assets in

Schedule one

2.19

1.45

0.43

0.24

0.045

3. Total $(1+2)$

3.46

0.88

0.34

0.064

4. Voluntary Zakat

Actually Collected

by LZCs

0.17

N.A

N.A

N.A

N.A

5. Ushr
(a) U1
0.32
0.12
0.16
0.023
0.015
(b) U2
0.66
0.26
0.30
0.06
0.036
(c) $\mathrm{U} 3$
1.58
0.59
0.78
0.15
0.065

6. Zakat and Ushr

Potential $(3+5 c)$

6.82

4.05

1.66

0.49

0.129

Source: Sample Survey, International Institute of Islamic Economics (IIIE), Islamabad, 1988, except data on official collection which were taken from Central Zakat Administration, Islamabad.

\section{Official Zakat Collection}

The amount of zakat actually collected by the Central Zakat Administration in a given year.

\section{Voluntary Zakat Collected}

This refers to the actual collection of voluntary zakat by LZC's in 1988 .

Ushr

This has been estimated using different types of responses received in our survey. Accordingly, $\mathrm{U} 1$ is the amount of ush actually collected by LZCs in 1988. This is a very low figure because only 75 percent of LZCs in the survey reported actually collecting $u s h r$ in that year; $\mathrm{U} 2$ is the amount of $u s h r$ if all farmers reported by 75 percent of LZCs' in the survey would have paid this levy; and finally $\mathrm{U} 3$ is the estimate based on the assessed value of ushr by 'general 
population' in our sample.

According to our estimates, the maximum potential of voluntary collection of zakat for 1988 comes to Rs 3.05 billion for Pakistan as a whole. Adding this figure to the total funds collected by CZA in 1988 from assets in Schedule One brings the total potential of zakat to Rs 5.24 billion.

As regards $u s h r$, even if we allow the highest possible estimate to hold i.e. U3, its potential comes to Rs 1.58 billion. $^{8}$ In this way the total potential of zakat and ushr for Pakistan as whole comes to Rs 6.82 billion.

\section{Estimates of Mustahqueen-e-Zakat (MZ)}

different estimates of the total number of $\mathrm{MZ}$ in the country are presented in Table 2. According to the information gathered from the general population, the total number of $\mathrm{MZ}$ comes to 5.46 million households, or 32.22 percent of the total households in Pakistan. This figure is slightly higher than the poverty estimates of about 29 percent calculated from other sources see Malik (1988).

In our survey we also tried to find out how many households in the general population could be Mustahqueen-e-Zakat. The present zakat recipients were then put together with those households to give us the figure of 3.116 million, or 18.4 percent of the total households in Pakistan. This estimate is quite low relative to the estimates obtained from other sources.

Another estimate of $\mathrm{MZ}$ could be the number of people who received zakat from LZCs so far. According to Table 2, this is equal to 3.967 million or 23.43 percent of the total households in Pakistan. From our survey of the general population, the fact that emerges clearly is that the official zakat system is not helping all $M Z$ in the country. The estimates in Row 3 in Table 2, therefore, do not represent the total size of MZ. According to our survey between 50 percent to 70 percent of $M Z$ have benefited from LZCs so far in one way or the other. If that is taken into consideration then the total number of $M Z$ in the country could be 7.21 million or 42.58 percent of the total households. (Row 4 of Table 2.)

The above estimates could be used to determine the minimum and maximum size of the MZ. The lowest figure of 18.4 percent could represent the

The obvious assumption here is that all assets coming under the purview of official zakat collection were subjected to this levy. If we allow some leakages which are not exactly known but are generally put to 10 percent then the official collection could go up by 10 percent.

Incidently this figure is quite in line with the estimates which the present author obtained using secondary data from Pakistan Census of Agriculture (1988). 
Table 2

Estimates of Number of Mustahqueen-e-Zakat in Pakistan by Region, 1988

(Rs: in Billion)

Balo-

Sources of Estimates

Pakistan Punjab Sindh NWFP chistan

1. Estimates Based on Assessment by the General Population 5.46

2.75

1.76

0.562

.3 .386

2. Households in

'General Population'

Considering Themselves

as Mustahqueen-e-

Zakat (MZ)

3.116

1.052

0.577

1.04

0.449

3. $\mathrm{MZ}$ Helped by LZCs

Till October 1988

$3.967 \quad 2.05$

1.10

0.623

0.194

4. MZ under the

Assumption that

not all of them as

Estimated in Row 1

Above have been

Helped so Far

7.21

3.06

2.44

1.17

0.54

Source: Sample Survey, IIIE, 1988.

most poor among $\mathrm{MZ}$ whereas the upper figure of $\mathbf{4 2 . 5 8}$ percent could also include those people who apparently are not poor but would qualify to receive zakat according to Islamic principles.

\section{FUNDS REQUIRED TO ERADICATE POVERTY \\ OF MUSTAHQUEEN-E-ZAKAT}

\section{Subsistence Needs}

We have worked out the funds required for Mustahqueen-e-Zakat, under alternative assumptions. In Table 3 Row 1 presents estimates of funds needed to fill the gap between current expenditures and income of 5.46 million $\mathrm{MZ}$, the number reported to have received some zakat from official sources in 1988. Accordingly the total additional funds needed come to Rs 7.89 billion. For the remaining (41 percent) of $\mathrm{MZ}$, who did not receive zakat in 1988, the shortfall is even more and comes to Rs 7.69 billion. In this way the sum of the two 
'shortfalls' is Rs 15.58 billion which is about 130 percent higher than the zakat potential of Rs 6.82 billion calculated earlier.

Table 3

Estimates of Annual Zakat Funds Needed for Subsistence of Mustahqueen-e-Zakat, Pakistan, 1988

(Rs in Billion)

Balo-

Pakistan Punjab Sindh NWFP chistan

1. Funds Needed to Meet

Shortfall in Expenditures

and Income of $\mathrm{MZ}$

Currently Receiving Zakat*

4.47

(67)

2.05

(45)

1.12

(53)

0.25

(36)

2. Funds Needed to Meet

the Shortfall in Expen-

ditures and Income of

those MZ not Receiving

Zakat at Present**

$\begin{array}{ll}7.69 & 2.6\end{array}$

(41)
3.08

(55)
1.05

(47)
0.51

\begin{tabular}{rlllll}
\hline Total Funds Needed & 15.58 & 7.07 & 5.13 & 2.17 & 0.76 \\
\hline
\end{tabular}

Source: Sample Survey, IIIE, 1988.

* Figures in brackets are percentage of MZ receiving zakat from official sources.

**.Figures in brackets are percentage of MZ not receiving zakat from official sources.

\section{Rehabilitation Needs}

Besides providing the subsistence allowance one of the important functions of the zakat system is to rehabilitate those Mustahqueen who have both the capability and willingness to do so. Our survey allowed us to develop a profile of $\mathrm{MZ}$ and separate those who indeed should be the target of any rehabilitation scheme.' On the basis of our survey data, therefore, we have tried to calculate the rehabilitation needs under alternative assumptions.

Table 4 shows estimates of rehabilitation funds needed for 25 percent of $\mathrm{MZ}$ under the assumption that 50 percent of them would like to go to business and the remaining 50 percent to "other professions" (or trades). Accordingly Rs 10.36 billion would be needed in one year to rehabilitate just 25 percent of MZ. When subsistence needs of the remaining 75 percent $M Z$ are added to this amount, the total zakat funds required in one year become about Rs 22 billion, nearly 2.25 times more than the potential of the existing system. The funds re-

${ }^{9}$ For details [see Mohammad'(1990), Ch. 8]. 
quirement would obviously change with the change in assumptions about the composition of zakat beneficiaries.

Table 4

Estimates of Zakat Funds Required for Rehabilitation and Subsistence of Mustahqueen-e-Zakat (MZ)

(Rs in Billion)

Balo-

Requirements

Pakistan Punjab Sindh NWFP chistan

(a) Assuming $25 \%$ of

MZ to be Rehabilitated

out of which:
(i) $50 \%$ in Business
4.4
1.85
1.32
0.95
0.28
(ii) $50 \%$ in other Trades
5.96
1.8
3.48
0.41
0.27

(b) Total (i \& ii)

10.36

3.65

4.80

1.36

0.55

(c) Funds Needed for

Subsistence of $75 \%$

of $\mathrm{MZ}$

5.30

3.84

1.63

0.57

(d) Total Requirements

$(b+c)$

22.05

8.95

8.64

2.99

1.12

(e) Zakat Potential as

percent of ' $d$ '

30.93

45.3

19.27

16.39

11.52

Source: Estimates for ' $i$ ' and 'ii' are based on data from Table 2 Row 1 and on the basis of survey information on the amount required by MZ for rehabilitating themselves in their desired profession. For details of these data see Mohammad (1990).

\section{CONCLUSIONS}

Our study shows that under the existing zakat system the potential funds even with maximum efforts are not sufficient to cater to the needs of the poor in the country. This is true even if we are to provide bare subsistence to the needy. On the other hand if efforts are made to permanently rehabilitate the $\mathrm{MZ}$, the fund requirements increase many times which just does not seem possible to be met from the existing system. Under this situation if zakat has to become a meaningful instrument of poverty eradication in Pakistan, the present system has to be substantially reformed. Some of the most important measures which can be suggested in this respect are as follows:

1 The practice of giving zakat exemption on various financial instruments 
(which are zakatable under Shariah) should be stopped;

2 Stock-in-trade (Amwal-e-Tajarah) should also be made part of the Schedule One;

3 Ushr collection may be extended to all agricultural items considered zakatable under Shariah. Moreover, the present ushr assessment method may be changed to control leakages;

4 Subsistence allowance may be provided only to the most poor and disabled ones among the MZ. The remaining MZ must be rehabilitated in small proportions every year by providing them a reasonable amount for starting a project. The present method of providing a small amount for rehabilitation cannot produce the desired results; and finally;

5 The zakat system must be revitalized at all levels to take a leading role in the process of poverty eradication. Unfortunately, over time it has been reduced to one of those departments which operate only on the fringes of the main government activities. This trend needs to be reversed.

\section{REFERENCES}

Ahmad, Irshad (1983) Zakat and Ushr System in Pakistan. Islamabad: Central Zakat Administration, Government of Pakistan. (Draft).

Butt, Pervez Ahmad (1990) Zakat Collection: A Case Study of Pakistan. Kualalumpur, Malaysia: Third Zakah Conference. May.

Malik, Muhammad Hussain (1988) Some New Evidence of Poverty in Pakistan. The Pakistan Development Review 23 : 4.

Mohammad, Faiz (1990) Evaluation of Nizam-e-Zikat and Ushr in Pakistan. Islamabad: International Institute of Islamic Economics, International Islamic University. (Unpublished.)

Pakistan, Government of (1988) Census of Agriculture. Islamabad: Ministry of Food and Agriculture, Agriculture Census Commission. Qardhavi, Yousaf (1981) Figh-ul-Zakat (Urdu), First and Second Volumes. Lahore: Al-Badar Publications. 


\section{Comments on \\ "Prospects of Poverty Eradication \\ Through the Existing Zakat System in Pakistan"}

To begin with, Dr Faiz Mohammad's paper on "The Prospect of Poverty Eradication Through the Zakat System in Pakistan" is an extremely interesting one. In addressing itself to the question, it inter alia seeks to assess the gap between the financial needs for eradicating poverty and the zakat potential in Pakistan. The present paper is, however, exploratory in nature, its scope having been restricted by non-availability of adequate data and a somewhat inappropriate sampling method.

The study is based on the survey of 257 Local Zakat Committees (LZCs) out of the universe of 36658 ; the sample works out to be less than 1 percent of the population. Furthermore, only 4-7 zakat recipients have been interviewed from each selected LZC, while an identical number of non-recipients of zakat have been interviewed to represent the general population of 5000-10000 people in each selected locality. Thus, the reliability of the sample is rather suspect. If all localities were characterized by identical variables than a small sample could perhaps be justified. However, the present sample could not be deemed representative of the diverse segments of population in Pakistan. Moreover, it is not clear as to how far the responses of the interviewees were reliable. To claim randomness for a deliberately structured sample is also open to question.

The Qur'an stipulates that zakah is for eight categories of recipients. Each category is subject to a wide range of interpretation in respect of eligibility. For instance, spending in the way of Allah has been interpreted to cover a narrow form of $j$ ihad (fighting in the battlefield) to an extended form such as expenditures on literacy efforts. Faiz Mohammad's contention that zakat is due to "the needy" only is also open to question.

Additionally, the paper skirts around the basic merits and demerits of the zakat system in Pakistan. Nor does it mention the malpractices in the management of zakat funds for political and personal gains.

According to the author, his survey does not generate estimates for the two groups of mustahaqueens-(1) subsistence poor needing regular financing and (2) poor needing rehabilitation. However, he takes it upon himself to give arbitrary figures - that, of course, without any reasonable basis. At another level, the 
estimates of ushr funds actually collected by LZCs were inflated arbitrarily to obtain the figure for maximum collectible ushr. Above all, the paper does not include the questionnaire sample which could have given some indication of the basis of the study.

All said and done, while the author does deserve commendation for undertaking a study on this important topic, the methodology needs to be refined and systematized to yield more reliable data which could become the base for analysis and policy formulation.

Muhammad Anwar

International Islamic University,

Malaysia. 